\title{
Stem Biomass Equation of Eucalyptus urophylla S.T. Blake
}

\author{
MELEWANTO PATABANG ${ }^{*}$, JULIANUS DISING ${ }^{2}$, ADRIN $^{3}$, AAH AHMAD ALMULQU \\ ${ }^{1}$ Department of Ecotourism, School of Vocational Studies, IPB University (Bogor Agricultural University) \\ Jl. Kumbang No.14, Bogor, West Java, Indonesia. 16128 \\ *Email: melewanto@yahoo.co.id \\ ${ }^{2}$ Department of Crop Plants and Horticulture, Politeknik Pertanian Negeri Kupang \\ Jl. Prof. Dr. Herman Johanes, Kupang, East Nusa Tenggara, Indonesia. 85228 \\ ${ }^{3}$ Department of Forestry, Politeknik Pertanian Negeri Kupang \\ Jl. Prof. Dr. Herman Johanes, Kupang, East Nusa Tenggara, Indonesia. 85228 \\ ${ }^{4}$ Faculty of Agriculture Natural Resources and Environment, University of Naresuan, Thailand \\ Tha Pho, Mueang Phitsanulok District, Phitsanulok 65000, Thailand
}

Received 29 August 2019; Received in revised form 01 December 2019;

Accepted 01 June 2019; Available online 30 June 2019

\begin{abstract}
Eucalyptus urophylla is one of the typical plants of the Province of East Nusa Tenggara, Indonesia whose distribution includes the islands of Timor, Alor, Wetor, Flores, Adonara, Lomblen, and Pantar. The best land for the growth of E. urophylla is an area with rainfall above $1000 \mathrm{~mm}$ every year. E. urophylla dominate the island of Timor hence the potential to absorb carbon and store it in biomass as part of climate change mitigation. This study aims to determine the allometric equation model to predict the potential of E. urophylla stem biomass. Calculation of the amount of stem biomass based on allometric equations is an analytical method used in this study. The sample trees used in equation modeling is 100 trees as a result of the inventory. The equations that can be used to estimate the biomass potential of the stem of E. urophylla in Timor Island were $\ln Y=-2.12+2.472 \ln (D)$ and $(\mathrm{R} 2=0.98) ; \ln Y=-3.617+1.046 \ln \left(D^{2} \times H\right)$ and $(\mathrm{R} 2=0.99)$; and $\ln Y=-3.510+2.157 \ln (D)+0.983 \ln (H)$ and $(\mathrm{R} 2=0.99)$. The stem biomass potential with the model I amounting to 276.877 tons ha $^{-1}$, model II of 279.671 tons ha ${ }^{-1}$, and model III of 280.209 tons $\mathrm{ha}^{-1}$.
\end{abstract}

Keywords: allometric; ampupu; biomass; East Nusa Tenggara; Eucalyptus urophylla

\section{INTRODUCTION}

The forest area of Timor Island, Indonesia is one of the forest areas that still has an area with a level of closure in the form of primary forest and secondary forest. The two types of closure are partly dominated by Eucalyptus urophylla. For example, the Gunung Mutis Nature Reserve is one of the typical forest areas in East Nusa Tenggara, hence it has a uniform and relatively intact E. urophylla. According to Li et al. (2015) E. urophylla is a family of Myrtaceae which has hardwood that can be used for various purposes and can grow and adapt well to the environment where it grows. E. urophylla is one of the plants that dominate Timor Island and is suitable to be used to predict the potential of stand biomass in forest areas in East Nusa Tenggara Province. The information about this biomass potency is very important to implementing climate change mitigation programs (Ochieng, 2017; Alloisio \& Borghesi, 2019; CIFOR, 2010). Other research that supports the calculation of the potential of Eucalyptus biomass has been carried out by Latifah \& Sulistiyono (2013) and Hernández-Ramos et al. (2017).

Allometric equations of Eucalyptus urophylla stem biomass on Timor Island are expected to be used as a basis for more accurately predicting E. urophylla tree biomass in order to support REDD + programs (Reducing Emissions from Deforestation and Forest Degradation). According to CIFOR (2010) one of the challenges faced in implementing REDD+ programs is the technology for calculating biomass and carbon. The technology for calculating carbon is one of the main challenges of the REDD+ program needs to find a solution and one way is to calculate biomass. Biomass is the amount of total organic matter living above ground in trees including leaves, twigs, branches, main stems and skins expressed in oven-dry weight tons per unit area. Biomass is an important measure to assess changes in forest structure, hence the distribution of forest biomass depends on the 
type of forest ecosystem (Grman et al., 2010; Le Toan et al., 2011; Saatchi et al., 2011; Achmad et al., 2013).

Tree biomass is the measure most often used to describe and study the potency of vegetation carbon storage. This is based on the fact that the estimation of biomass is relatively easier to measure and is an accumulation of the total metabolic processes experienced by plants so this is a fairly representative indicator of growth when associated with the overall appearance of plant growth (Pamoengkas et al., 2000). According to Elias \& Wistara (2009) estimation of biomass is a major challenge in tropical forestry research because of the variety of biodiversity and forest types. The main way to calculate biomass is through: Destructive sampling, non-destructive sampling through remote sensing, and modeling (Sutaryo, 2009). Vahedi et al., (2014) and Picard et al., (2012) suggested that approaches with destructive methods were used to develop allometric equations that would allow us to estimate tree masses from several simple measurements, which then this equation model could be applied to trees in forest areas.

In comparison, several studies have used allometric equations to predict biomass, including Latifah \& Sulistiyono (2013) and Chave et al. (2014). Allometric equations in this study represent the form of general equations developed by Chave et al. (2005) and Basuki et al. (2009). The allometric equation used in this study illustrates the relationship between biomass with diameter and height, Stem biomass is calculated using a volume approach where wood density is used as a conversion factor. The results of these studies indicate that allometric equations are reliable enough to be used in predicting tree biomass content which is known to have a significant relationship between diameter and height with tree biomass. In the case of model applications, allometric equations will give different results if done on different species and locations. However, in terms of the composition of variables and forms of equations, various allometric equations can be compared to get the best model. For the type of Eucalyptus, the treatment (irrigation and fertilization) will not affect the allometric equations used because the same allometric equations can be used for all types of treatment given (Stape et al., 2008).

Allometric equations to estimate the biomass or volume potential of the genus Eucalyptus have been widely developed, among others, for Eucalyptus deglupta by Sarmiento \& Varela (2015). In the study, they used allometric equations which state the relationship between biomass with diameter and tree height to predict the potential of tree biomass based on age class. According to Forrester et al. (2017) allometric equations are generally made based on the specific conditions of the area where it grows. According to Henry et al. (2011), allometric equations used to predict tree biomass from botanical features that are tree diameter or height which are key factors to predict the contribution made by forest ecosystems to the carbon cycle. Estimation of individual tree biomass is usually based on allometric between easily measurable dimensions such as diameter at breast height (DBH) and biomass. According to Fonseca et al. (2011) the highest carbon stock and tree biomass were found in tree-based biomass at ground level which was $66.3 \%$ of the total tree biomass. According to Devine et al. (2013) the accuracy of estimates of tree biomass depends on how well allometric equations represent a type of tree. The use of global allometric equations that have been published is often done, because the coefficient of allometric equations varies for each location and species, the use of this global equation can cause a significant error in estimating biomass of vegetation. This study aims to: (1) developing the model for estimating the biomass of Eucalyptus urophylla stem, (2) Providing the information of biomass and carbon stock of Eucalyptus urophylla stands in the study area.

\section{MATERIALS AND METHODS}

Data Collection. Data collection was carried out on inventory in Eucalyptus urophylla stands using systematic sampling with random start in three locations. Data collection is provided at every location using the plots form a square with a size of 20 meter x 20 meter at each location. The shape and size 
of the plot are also used by Widyasari et al. (2010) to predict the potency of tree biomass. The number of tree samples is 30-35 trees in each location. The individuals were grouped into three DBH classes: $11-30,31-50$ and $\geq 51$ $\mathrm{cm}$, which is a general diameter classification base on distribution DBH in study area. For each sample tree the $\mathrm{DBH}$ and total height $(\mathrm{H})$ of the stand trees were first recorded in all diameter class (Ostadhashemi et al. 2014; Vahedi et al. 2014.). Sampling locations were carried out in three locations:

1. The first location to position fastening point $9^{\circ} 38^{\prime} 41.31^{\prime \prime}$ South latitude and $124^{\circ} 16^{\prime} 24.36^{\prime \prime}$ East longitude that the administrator $\mathrm{f}$ included in the region Tune Village

2. The second location to tie point position $9^{\circ} 38^{\prime} 43.31^{\prime \prime} \quad$ South latitude and 1241'11:04" east longitude which is administratively included in the Fatumnasi Village

3. The third location with connective point position $9^{\circ} 38^{\prime} 53.40^{\prime \prime}$ South latitude and $124^{\circ} 16^{\prime} 4.97^{\prime \prime}$ East longitude which is administratively included in Tutem Village.

To estimate wood density, three tress were for every DBH class to represent the diameter distribution reported in the stands. The tree stem should be cut into three parts (base, middle, top) logs to take account of wood density and moisture content variations in the part of stem. Wood density is also different at the top (Iida et al., 2012) and base (Greenwood et al., 2017) of the tree (young wood near the crown, high proportion of adult wood toward the base but it may also vary according to the condition of the tree's growth including changes in proportion between early and late wood, annual ring width, and changes in cell structure and properties (Genet et al., 2013; Pretzsch et al., 2018; Erdene-Ochir et al., 2020). Samples about $10 \mathrm{~cm}$ (disk) long should be taken of the each part of the stem (Picard et al. 2012). About 10 disks should be taken for base, middle and top stem respectively. The number of sub samples analyzed to calculate the wood density is 90 disk. Wood density of the Eucalyptus urophylla erectness was determined according to SNI calculation (Ruslandi \& Suprianto, 2012) by taking the base part, middle, and top of wood from sample trees. Then measured for length, diameter, and weighted for its wet weight, after that put into an oven at a temperature of $103 \pm 5^{\circ} \mathrm{C}$ for 24 hours and then weighted it to obtain its dry weight.

The wood density data from the laboratory analysis was then used to calculate the biomass content of individual trees is aby a product of the volume byand wood density ( $\mathrm{V} \times \mathrm{K})$. For development of the regression equations, we we used 100 sample trees of stand inventory. The biomass of 100 individual trees was calculated by multiplying the volume and wood desitydensity based on diameter class. All empirical relationships 100 trees were included in the existing allometric equations, and the explanatory variables are always diameter at breast height $(\mathrm{DBH})$, tree height $(\mathrm{h})$, or a combination of the two (Table 3).

Data Analysis. Analysis of volume and stem biomass data to be calculated in this study is to branch-free height. Calculation of stem volume and biomass is carried out using the equation that has been used by Ostadhashemi et al. (2014) as follows:

$$
V=b a \times H \times f
$$

Note: $V=$ Stem volume $\left(\mathrm{m}^{3}\right)$, ba $=$ basal area $\left(\mathrm{m}^{2}\right), H=$ Branch free height $(\mathrm{m}), \mathrm{f}=$ correction factor $(=0.7)$.

$$
Y=V \times K
$$

Note: $Y=Y=$ Biomass $(\mathrm{kg}), V=$ Stem volume $\left(\mathrm{m}^{3}\right), K=$ wood density $\left(\mathrm{kg} \cdot \mathrm{m}^{-3}\right)$.

The density of wood from E. urophylla stands is based on SNI calculation (Ruslandi \& Suprianto, 2012) by taking the base, middle and wood end of the sample tree, then measuring the length, diameter and weighing the wet weight after being put into the oven at $103 \pm$ $5^{\circ} \mathrm{C}$ for 24 hours and weighed the dry weight (Yuniati \& Kurniawan, 2013). Furthermore, the calculation of wood density was carried out based on the equation used by Latifah \& Sulistiyono (2013), fiber Yusuf et al. (2014) as follows: 


$$
K=\frac{M}{V}
$$

Note: $\mathrm{K}=$ wood density $\left(\mathrm{kg} / \mathrm{m}^{3}\right), \mathrm{M}=$ wood oven-dry weight $(\mathrm{kg}), \mathrm{V}=$ volume of sample $\left(\mathrm{m}^{3}\right)$

The potential of stem biomass for all study areas was carried out using allometric equations to find the relationship between biomass and tree dimensions. According to Ostadhashemi et al. (2014) allometric equations are very suitable for calculating aboveground biomass. The nature studies have used some similarities allometric to determine the relationship between the sizes of the tree (diameter or height) with biomass. The value of stem biomass used in preparing the model is obtained from the results of the volume conversion to biomass based on equation 2 by using wood density values. Allometric equations used in this study are equations that have been used by several previous researchers such as Basuki et al. (2009), Elias \& Wistara (2009), Sutaryo (2009), Widyasari et al. (2010), and Vahedi et al. (2014). This allometric equation is a development of the equation suggested by Brown (1997) as follows:

$$
\ln Y=\operatorname{Exp}(a+b \ln D)
$$

$$
\begin{aligned}
& \ln Y=a+b \ln \left(D^{2}+T\right) \ldots \\
& \ln Y=a+b \ln D+c \ln T
\end{aligned}
$$

Note: $Y=$ total biomass stem $(\mathrm{kg}), a, b=$ regression coefficient, $D=$ diameter at breast height $(\mathrm{cm}), T=$ branch free height $(\mathrm{m})$

To select the allometric equation model produced, validation of the reliability of the model was carried out. The reliability of allometric equation models was tested based on the value of the Determination Coefficient and $\mathrm{t}$ (Akbar, 2012; Vahedi et al. 2014). The estimation of biomass stem potential of $E$. urophylla stand was performed by using the medium value estimation sampling (Picard $e t$ al., 2012). with the following equation:

$$
B \pm t_{n-1} \frac{S_{B}}{\sqrt{n-1}}
$$

Note: $t n-1$ is the quantile $1-\alpha / 2$ of a Student distribution with $n-1$ degrees of freedom, and $S B$ is the empirical standard deviation of plot biomass.

$S_{B}^{2}=\frac{1}{n-1} \sum_{i=1}^{n}\left(B_{i}-\bar{B}\right)^{2}$

Note:

$B_{i}=$ Biomass of the $i$-th plot

$B=$ mean biomass of a plot

$\mathrm{S}_{\mathrm{B}}^{2}=$ standard deviation of plot biomass

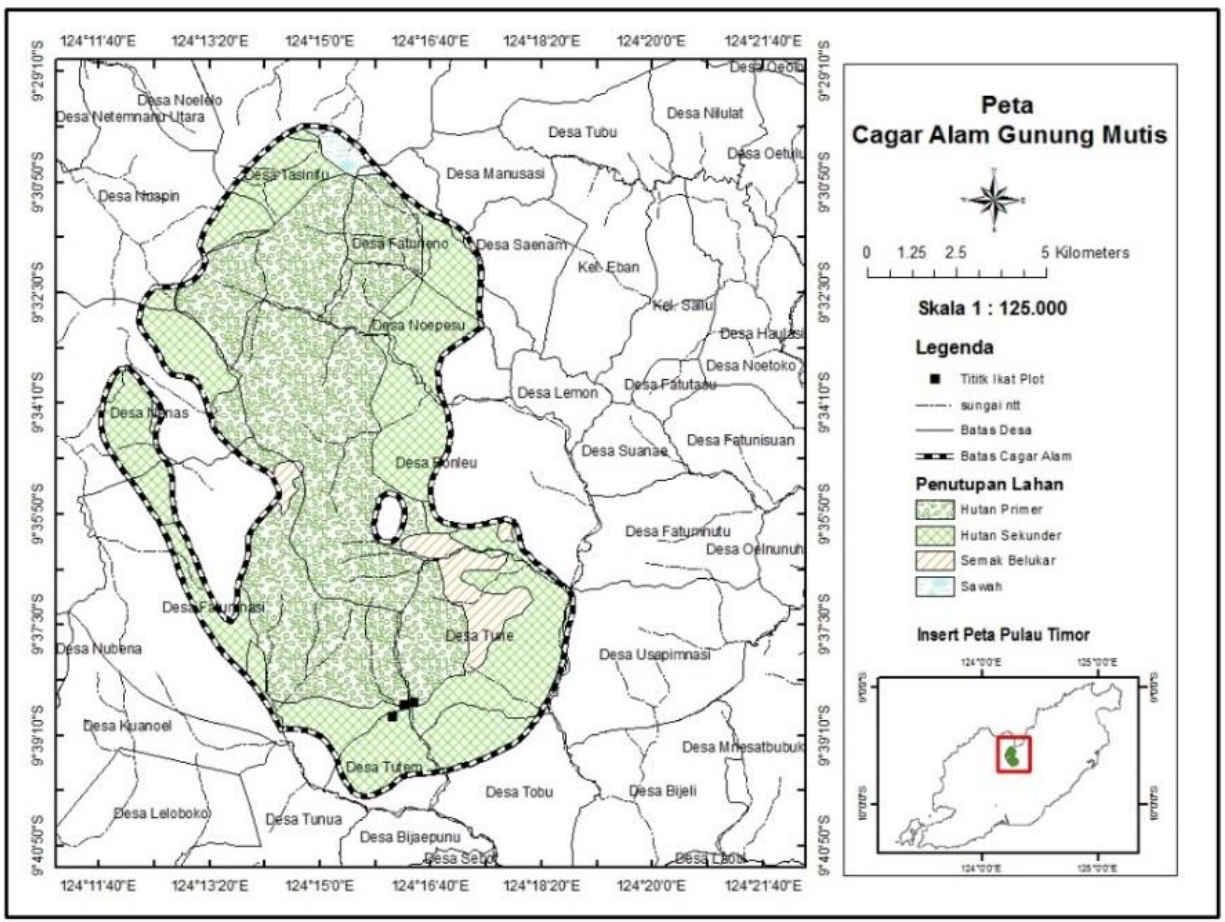

Figure 1. Map of Map of Gunung Mutis Nature Reserve showing three sampling sites 
RESULT AND DISCUSSION

Wood Density and Biomass Stem. The calculation of biomass in this study was carried out in the sample tree by taking each part of the stem of the tree as samples to be observed. The sample is then oven until it reaches the dry weight of the furnace. After that, it is weighed to obtain the value of weight or mass of wood in units of grams (equation 3). The results of the analysis of the wood density and biomass of each part of the stem in detail are presented in Table 1.

Table 1. Average wood density and biomass stem of laboratory analysis

\begin{tabular}{|c|c|c|c|c|c|}
\hline Diameter Class & Part of Stem & $\mathbf{n}$ & $\begin{array}{c}\text { Wood Density } \\
\left({\left.\mathrm{g} . \mathrm{cm}^{-3}\right)}^{-3}\right.\end{array}$ & Volume $\left(\mathbf{m}^{\mathbf{3}}\right)$ & Biomass (kg) \\
\hline \multirow{3}{*}{ I } & Top & 3 & 0.78 & 0.08 & 64.80 \\
\hline & Middle & 3 & 0.90 & 0.16 & 142.11 \\
\hline & Bottom & 3 & 0.91 & 0.29 & 261.68 \\
\hline \multirow{3}{*}{ II } & Top & 3 & 0.85 & 0.58 & 493.93 \\
\hline & Middle & 3 & 0.91 & 0.86 & 778.84 \\
\hline & Bottom & 3 & 0.94 & 1.26 & 1187.21 \\
\hline \multirow{3}{*}{ III } & Top & 3 & 0.87 & 1.42 & 1239.02 \\
\hline & Middle & 3 & 0.93 & 2.69 & 2502.97 \\
\hline & Bottom & 3 & 0.99 & 3.87 & 3827.63 \\
\hline
\end{tabular}

The results of the analysis in Table 1 show that the average wood density of individual sample stem diameter class I is $0.86 \mathrm{~g} . \mathrm{cm}^{-3}$ with a biomass content of $468.59 \mathrm{~kg} \cdot \mathrm{tree}^{-1}$. The average value of wood density for trees stem with diameter class II is $0.90 \mathrm{~g} \cdot \mathrm{cm}^{-3}$ with a biomass content of $2459.99 \mathrm{~kg}$ tree- 1 . The average value of wood density for trees stem with diameter class III is $0.93 \mathrm{~g} . \mathrm{cm}^{-3}$ with a biomass content of $7569.81 \mathrm{~kg}^{-\mathrm{tree}^{-1}}$. The results of the analysis in Table 1 also show that the part of the stem that has the smallest biomass is the top and the biggest part is the base of the stem. This result is also supported by research by Fonseca et al. (2011) which states that the highest tree biomass is found in tree-based biomass at ground level which is $66.3 \%$ of the total tree biomass.
Allometric Equation Model. Modeling the equation in this study was carried out by a destructive method. The wood density data from the laboratory analysis was then used to calculate the biomass content of trees is a product of volume and wood density ( $\mathrm{V} \times \mathrm{K}$ ). For development of the regression equations, we measured the diameter and height of 100 trees, which represented the diameter classes (Table 1) in the studied stands. The biomass trees calculated in this study are the result presented in Table 2. Data in table 2 was analyzed using regression analysis based on equations 2, equation 3 and equation 4 . In this allometric equation, the value variables analyzed are stem biomass $(Y)$, diameter $(D)$ and tree height $(\mathrm{T})$. The results of the regression analysis of 100 tree samples was presented in Table 3 and Figure 2.

Table 2. Descriptive statistic of tree sample used to build model

\begin{tabular}{lcrrrr} 
& N & Range & Minimum & Maximum & \multicolumn{2}{c}{ Standar Deviation } \\
\hline Diameter $(\mathbf{c m})$ & 100 & 71.70 & 11.10 & 82.80 & 18.57 \\
\hline Height $(\mathbf{m})$ & 100 & 12.00 & 8.00 & 20.00 & 2.91 \\
\hline Biomass $(\mathbf{k g})$ & 100 & 5857.61 & 52.72 & 5910.33 & 1435.32 \\
\hline
\end{tabular}

Table 3. Description of the equation model for estimating biomass of Eucalyptus urophylla stem in the study area

\begin{tabular}{ccccccccc}
\hline \multirow{2}{*}{ Model } & \multirow{2}{*}{ Equation } & a & b & c & $\begin{array}{c}\text { Standard } \\
\text { Error }\end{array}$ & $\begin{array}{c}\mathrm{R}^{2} \text { adj } \\
(\%)\end{array}$ & \multirow{2}{*}{$\mathrm{F}$} & Sig. \\
\hline $\mathrm{I}$ & $\ln Y=a+b \ln (D)$ & -2.12 & 2.47 & - & 0.15 & 98.8 & 8241.42 & 0.000
\end{tabular}




\begin{tabular}{|c|c|c|c|c|c|c|c|c|c|}
\hline II & $\ln Y=a+b \ln (D$ & $\times H)$ & -3.62 & 1.06 & - & 0.06 & 99.8 & 59263.19 & 0.000 \\
\hline III & $\ln Y=a+b \ln (D$ & $+c \ln (H)$ & -3.51 & 2.16 & 0.9 & 0.06 & 99.8 & 30623.32 & 0.000 \\
\hline
\end{tabular}

Note: $\mathrm{Y}=$ Stem Biomass $(\mathrm{kg}), \mathrm{D}=$ Diameter of human breast height $(\mathrm{cm}), \mathrm{H}=$ Branch free height $(\mathrm{m})$
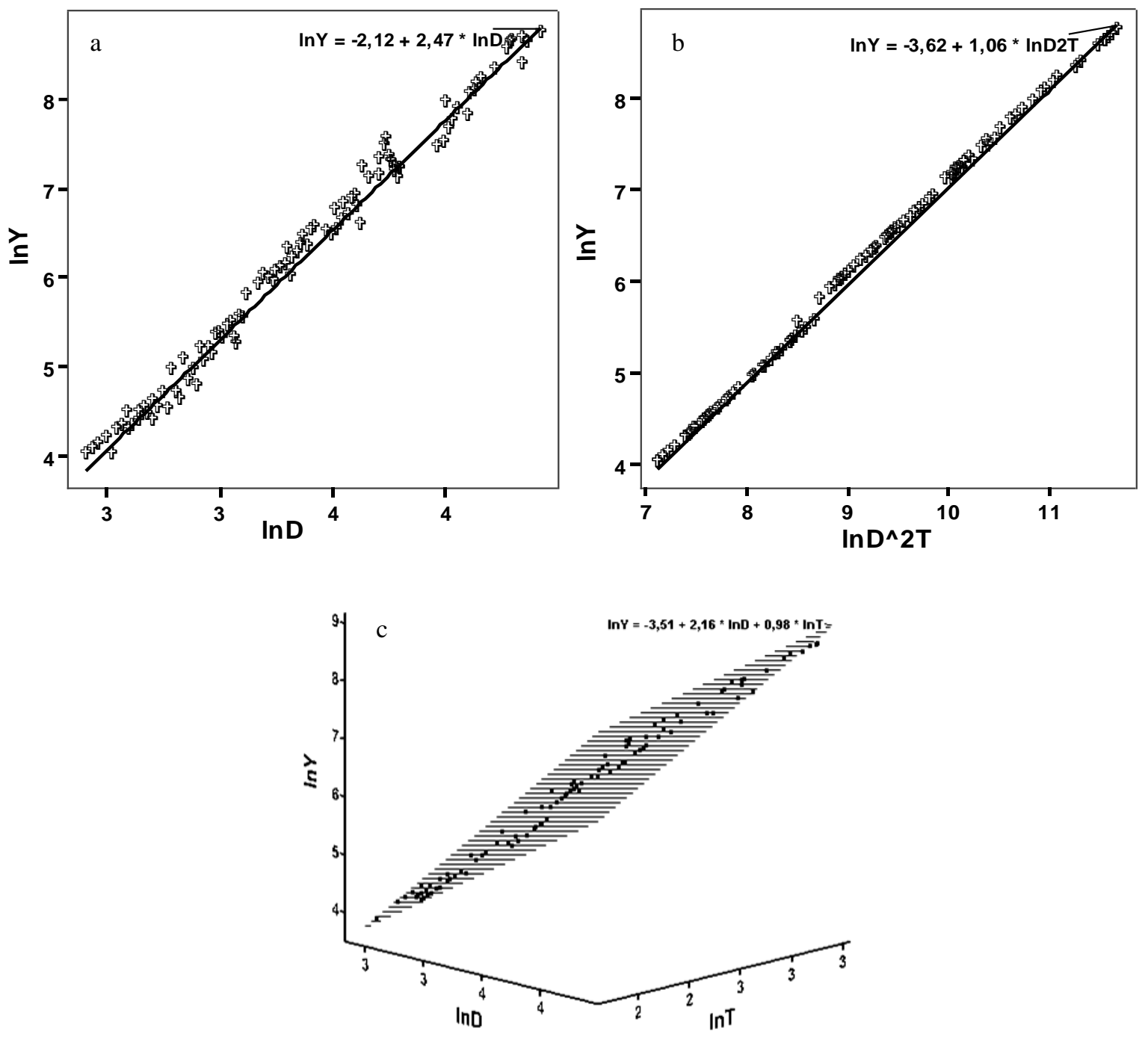

Figure 2. The regression analysis of 100 tree samples: a. Regression between the natural logarithm of stem biomass (kg) and the natural logarithm of the of diameter $(\mathrm{cm}) ; \mathrm{b}$. Multivariate regression between the natural logarithm of stem biomass $(\mathrm{kg})$ and the natural logarithm of the product of square diameter and height (x); c. Multivariate regression between the natural logarithm of stem biomass $(\mathrm{kg})$ and the natural logarithm of the diameter $(x)(\mathrm{cm})$ and the natural logarithm of the height $(z)(\mathrm{m})$

The results of the data analysis in Table 3 and Figure 2 shows that there is a very significant relationship between stem biomass and diameter and the height of the Eucalyptus urophylla tree. This can be known from the significance value (Sig. $<0.01$ ). Table 2 shows that equation II has the largest $\mathrm{R}$ and $\mathrm{F}$ values. When compared from the data distribution in Figure 2, it can be seen that eq. II and eq. II has the best data distribution. This result also (eq. II dan eq. III) indicates that the allometric models including $\mathrm{D}, \mathrm{H}$ had a higher precision data than the models including only diameter. According to Vahedi et al. (2014) two different explanatory variables (D and $\mathrm{H}$ ) was the best estimator for the total aboveground biomass prediction for each single species.

Other relationship patterns also indicated by the coefficient of determination $\left(\mathrm{R}^{2}\right)$ with a value for all the models ranged from $98.8 \%$ to $99.8 \%$. This value indicates that the independent variable in the form of diameter and height can determine more than $90 \%$ of the dependent variable, biomass. This is in line 
with the results of research by Basuki et al. (2009), Akbar (2012), Latifah \& Suistiyono (2013), Huy et al. (2016) which uses the same allometric equation model to estimate tree biomass based on the value of diameter and tree height. These equation models are allometric equation models developed by Brown (1997) and linear equation models with the transformation of natural logarithms that have been used by several previous researchers about biomass. The results of the analysis in Table 3 also show that the model II and III equations are the best models because they produce the smallest standard error values and the largest $\mathrm{R}^{2}$ adj.

Further analysis of this equation model was carried out using the $t$ test. This test is carried out on the value of the calculation of the sample tree if it is converted into the model equation that has been obtained (3 Equation Models). This test is conducted to determine the differences in the results of the equation model. The results of this t-test analysis in detail are presented in Table 4 . The results of the analysis in Table 4 show that the model eq. I, model eq. II and model eq. III show results that are not significantly different as indicated by the significance value which is smaller than 0.01 (sig. $<0.01$ ).

The results of this equation comparison test (Table 4) are in line with the results of Vahedi et al. (2014) which shows that not all allometric equation models used to predict biomass of a plant type are not significantly different. Adding the height to the equation (eq. II and eq. III) can't be affect significant but can be increase $\mathrm{F}$ and coefficient correlation.

Table 4. Paired $t$-test at $95 \%$ confidence interval of the mean of stem biomass (kg) Eucalyptus urophylla

\begin{tabular}{cllrrrr}
\hline No. & \multicolumn{1}{c}{ Equation Comparison } & N & Standard Deviation & t count & Sig. \\
\hline $\mathbf{1}$ & Model eq. I vs. Model eq. II & 100 & 283.301 & -0.552 & 0.582 \\
\hline $\mathbf{2}$ & Model eq. I vs. Model eq. III & 100 & 263.910 & -0.674 & 0.502 \\
\hline $\mathbf{3}$ & Model eq. II vs. Model eq. III & 100 & 20.534 & -1.048 & 0.297
\end{tabular}

Biomass Potential and Standing Carbon

Content. The results of the analysis of stem biomass potential based on allometric equations previously obtained (Table 5) are then used to calculate the individual biomass 100 trees sample. The potential of stem biomass calculated and analyzed using the mean value estimation method (eq. 7 and eq. 8). The results of the analysis in Table 3 show that the stem biomass potential with the model I amounting to 276.877 tons ha $^{-1}$, model II of 279.671 tons ha $^{-1}$, and model III of 280.209 tons ha $^{-1}$.

Table 5. Estimated potential of biomass and carbon Eucalyptus urophylla study area

\begin{tabular}{|c|c|c|c|c|c|}
\hline Model & Equation & Diameter class & $\begin{array}{c}\text { Standard } \\
\text { Error }\end{array}$ & $\begin{array}{l}\text { Biomass } \\
\left(\text { ton } \text { ha }^{-1}\right)\end{array}$ & $\begin{array}{c}\text { Carbon } \\
\left(\text { ton } \text { ha }^{-1}\right)\end{array}$ \\
\hline \multirow{3}{*}{$\mathbf{I}$} & \multirow{3}{*}{$\ln Y=-2.166+2.472 \ln (D)$} & 1 & 4.023 & 12.222 & 5.530 \\
\hline & & 2 & 11.948 & 56.771 & 25.689 \\
\hline & & 3 & 51.654 & 207.884 & 94.068 \\
\hline \multirow{3}{*}{ II } & \multirow{3}{*}{$\ln Y=-3.617+1.046 \ln \left(D^{2} \times H\right)$} & 1 & 4.168 & 12.090 & 5.471 \\
\hline & & 2 & 17.420 & 61.180 & 27.684 \\
\hline & & 3 & 60.953 & 206.401 & 93.396 \\
\hline \multirow{3}{*}{ III } & \multirow{3}{*}{$\ln Y=-3.510+2.157 \ln (D)+0.983 \ln (H)$} & 1 & 4.158 & 12.099 & 5.475 \\
\hline & & 2 & 16.949 & 60.908 & 27.561 \\
\hline & & 3 & 60.429 & 207.202 & 93.759 \\
\hline
\end{tabular}

\section{CONCLUSION}

The part of the stem that has the smallest wood density is the top and the largest part is the bottom of stem with an average wood density range of $0.78-0.99$ g. $\mathrm{cm}^{-3}$. The results of the calculation of the stem biomass in this study indicate that the range value of biomass content of part the stem is $64.80-3827.63 \mathrm{~kg}$. The best allometric equation from the results of this study that can be used to estimate the biomass content of Eucalyptus urophylla species is: $\ln Y=-2.12+2.472 \ln (D)$ and $\ln Y$ 
$=-3.617+1.046 \ln \left(D^{2} \times H\right)$. The stem biomass potential with the model I amounting to 276.877 tons $\mathrm{ha}^{-1}$, model II of 279.671 tons $\mathrm{ha}^{-1}$, and model III of 280.209 tons ha ${ }^{-1}$.

\section{ACKNOWLEDGMENTS}

We thank the Directorate General of Research and Community Service Strengthening, the Ministry of Research, Technology and Higher Education for providing financial assistance for the implementation of this research activity.

\section{REFERENCES}

Achmad E, Jaya INS, Saleh MB, Kuncahyo B. 2013. Biomass estimation using ALOS PALSAR for identification of lowland forest transition ecosystem in Jambi Province. Journal of Tropical Forest Management. vol 19(2): 145-155. doi: https://doi.org/10.7226/jtfm.19.2.145.

Akbar A. 2012. Persamaan alometrik untuk menduga kandungan karbon jenis meranti (Shorea teysmaniana) di hutan alam rawa gambut Kalimantan Tengah (Allometric equations for predicting carbon contents of shorea teysmaniana in peat swamp Natural Forest Central Kalimantan). Jurnal Penelitian Sosial dan Ekonomi Kehutanan. vol 9(1): 1-11. doi: https://doi.org/10.20886/jpsek.2012.9.1.1-11.

Alloisio I, Borghesi S. 2019. Climate change mitigation. In: Leal Filho W, Azeiteiro U, Azul A, Brandli L, Özuyar P, Wall T. (eds) climate action. Encyclopedia of the UN Sustainable Development Goals. Cam: Springer. p. 57

Basuki TM, van Laake PE, Skidmore AK, Hussin YA. 2009. Allometric equations for estimating the above-ground biomass in tropical lowland Dipterocarp forests. Journal Forest Ecology and Management. vol 257: 1684-1694. doi: https://doi.org/10.1016/j.foreco.2009.01.027.

Brown S. 1997. Estimating Biomass and biomass change of tropical forest. FAO Forestry Paper. Urbana: FAO. p. 1-55.

Chave J, Andalo C, Brown S, Cairns MA, Chambers JQ, Eamus D, Folster H, Fromard F, Higuchi N, Kira T, Lescure JP, Nelson bw, Ogawa H, Puig H, Riéra B, Yamakura T. 2005. Tree allometry and improved estimation of carbon stocks and balance in tropical forests. Oecologia. vol 145: 87-99. doi: https://doi.org/10.1007/s00442-005-0100-x.

Chave J, Mechain MR, Burquez A, Chidumayo E, Colgan MS, Delitti WBC, Duque A, Eid T, Fearnside PM, Goodman RC, Henry M, Yrizar AM, Mugasha WA, Landau HCM, Mencuccini M, Nelson BW, Ngomanda A, Nogueira EM, Malavassi EO, Pelissier R, Ploton P, Ryan CM, Saldarriaga JG, Vieilledent G. 2014. Improved allometric models to estimate the aboveground biomass of tropical trees. Global Change Biology. vol 20: 3177-3190. doi: https://doi.org/10.1111/gcb.12629.

CIFOR. 2010. Pedoman CIFOR tentang hutan, perubahan iklim dan REDD (CIFOR guide on forest, climate change and REDD). Bogor: CIFOR. hal. 4.

Devine WD, Footen PW, Harrison RB, Terry TA, Harrington CA, Holub SM, Gould PJ. 2013. Estimating tree biomass, carbon, and nitrogen in two vegetation control treatments in an 11-year-Old Douglas-Fir plantation on a highly productive site. [Research Paper]. Estacada: United States Department of Agriculture Forest Service Pacific. p. 1.

Elias, Wistara NJ. 2009. Metode estimasi massa karbon pohon Jeunjing (Paraserianthes falcataria L. Nielsen) di Hutan Rakyat. Journal of Tropical Forest Management. vol 15(2): 75-82.

Erdene-Ochir T, Ishiguri F, Nezu I, Tumenjargal B, Baasan B, Chultem G, Ohshima J, Yokota, S. 2020. Utilization potential of naturally regenerated Mongolian Betula platyphylla wood based on growth characteristics and wood properties. Silva Fenn. vol 54(3): 1-16. doi: https://doi.org/10.14214/sf.10284.

Fonseca W, Alice FE, Rey-Benayas JM. 2011. Carbon accumulation in aboveground and belowground biomass and soil of different age native forest plantations in the humid tropical lowlands of Costa Rica. New Forests. vol 43: 197-211. doi: https://doi.org/10.1016/j.foreco.2011.06.036.

Forrester DI, Tachauer IHH, Annighoefer P, Barbeito I, Pretzsch H, Peinado RR, Stark H, Vacchiano, G, Zlatanov T, Chakraborty T, Saha S, Sileshi GW. 2017. Generalized biomass and leaf area allometric equations for European tree species incorporating stand structure, tree age and climate. Journal Forest Ecology and Management. vol 396: 160-175. doi: https://doi.org/10.1016/j.foreco.2017.04.011.

Genet A, Auty D, Achim A, Bernier M, Pothier D, Cogliastro A. 2013. Consequences of faster growth for wood density in northern red oak (Quercus rubra Liebl.). Forestry. vol 86(1): 99-110. doi: https://doi.org/10.1093/forestry/cps057.

Greenwood S, Ruiz-Benito P, Martínez-Vilalta J, Lloret F, Kitzberger T, Allen CD, Fensham R, Laughlin DC, Kattge J, Bönisch G, Kraft NJ. 2017. Tree mortality across biomes is promoted by drought intensity, lower wood density and higher specific leaf area. Ecology Letters. vol 20(4): 539-553. doi: https://doi.org/10.1111/ele.12748.

Grman E, Lau JA, Schoolmaster Jr DR, Gross KL. 2010. Mechanisms contributing to stability in ecosystem function depend on the environmental context. Ecology letters. vol 13(11): 1400-1410. doi: https://doi.org/10.1111/j.1461-0248.2010.01533.x.

Henry M, Picard N, Trotta C, Manlay RJ, Valentini R, Bernoux M, Saint-André L. 2011. Estimating tree biomass of sub-Saharan African forests: a review of 
available allometric equations. Silva Fennica. vol 45(3): 477-569. doi: https://doi.org/10.14214/sf.38.

Hernández-Ramos J, Santos-Posadas HMD, ValdezLazalde JR, Tamarit-Urias JC, Ángeles-Pérez G, Hernández-Ramos A, Peduzzi A, Carrero O. 2017. Aboveground biomass and expansion factors in commercial forest plantations of Eucalyptus urophylla S. T. Blake. Agrociencia. vol 51(8): 921938.

Huy B, Poudel KP, Kralicek K, Hung ND, Khoa PV, Phuong PT, Temesgen H. 2016. Allometric equations for estimating tree aboveground biomass in tropical dipterocarp forests of Vietnam. Journal Forests. vol 7: 180-199. doi: https://doi.org/10.3390/f7080180.

Iida Y, Poorter L, Sterck FJ, Kassim AR, Kubo T, Potts MD, Kohyama TS. 2012. Wood density explains architectural differentiation across 145 cooccurring tropical tree species. Functional Ecology. vol 26(1): 274-282. doi: https://doi.org/10.1111/j.1365-2435.2011.01921.x

Latifah S, Sulistiyono N. 2013. Carbon Sequestration Potential in aboveground Biomass of Hybrid Eucalyptus Plantation Forest. Journal of Tropical Forest Management. vol 19(1): 54-62. doi: https://doi.org/10.7226/jtfm.19.1.54.

Li LM, Ouyang LJ, Gan SM. 2015. Towards an efficient regeneration protocol for Eucalyptus urophylla. Journal of Tropical Forest Science. vol 27(3): 289297.

Le Toan T, Quegan S, Davidson MWJ, Balzter H, Paillou P, Papathanassiou K, Plummer S, Rocca F, Saatchi S, Shugart H, Ulander L. 2011. The BIOMASS mission: Mapping global forest biomass to better understand the terrestrial carbon cycle. Remote sensing of environment. vol 115(11): 2850-2860. doi: https://doi.org/10.1016/j.rse.2011.03.020.

Ochieng RM. 2017. The role of forests in climate change mitigation: A discursive institutional analysis of REDD+ MRV. [Dissertation], Wageningen: Wageningen University. p. 115-141. doi: https://doi.org/10.18174/412210.

Ostadhashemi R, Shahraji TR, Roehle H, Limaei SM. 2014. Estimation of biomass and carbon storage of tree plantations in northern Iran. Journal of Forest Science. vol 6(9): 363-371.

Pamoengkas P, van Noordwijk M, Indrawan. 2000. Pendugaan biomassa pohon berdasarkan model fractal branching pada hutan sekunder di Rantau Pandan, Jambi. Jurnal Manajemen Hutan Tropika. vol 6 (1): 1-5.

Picard N, Saint-André L, Henry M. 2012. Manual for building tree volume and biomass allometric equations from field measurement to prediction.
Rome: Food and Agriculture Organization of the United Nations. pp. 23-187.

Pretzsch H, Biber P, Schütze G, Kemmerer J, Uhl E. 2018. Wood density reduced while wood volume growth accelerated in Central European forests since 1870. Forest Ecology and Management. vol 429: 589-616. doi: https://doi.org/10.1016/j.foreco.2018.07.045.

Ruslandi, Suprianto T. 2012 Petunjuk Teknis Pengukuran Stok Karbon Pada Plot Contoh National Forest Inventory: Seri Metodologi. Jakarta: UN-REDD Programme Indonesia. hal. 40

Sarmiento RT, Varela RP. 2015. Assessing the biomass potential of major industrial tree plantation species for green energy production. Open Journal of Forestry. vol 5(5): 557-562. doi: https://doi.org/10.4236/ojf.2015.55049.

Saatchi S, Marlier M, Chazdon RL, Clark DB, Russell AE. 2011. Impact of spatial variability of tropical forest structure on radar estimation of aboveground biomass. Remote Sensing of Environment. vol 115(11): 2836-2849. doi: https://doi.org/10.1016/j.rse.2010.07.015.

Stape JL, Binkley D, Ryan MG. 2008. Production and carbon allocation in a clonal Eucalyptus plantation with water and nutrient manipulations. Journal of Forest Ecology and Management. vol 255(3-4): 920-930. https://doi.org/10.1016/j.foreco.2007.09.085.

Sutaryo D. 2009. Penghitungan Biomassa: Sebuah pengantar untuk studi karbon dan perdagangan karbon. Bogor: Wetlands International Indonesia Programme. hal. 5

Vahedi AA, Mataji A, Babayi-Kafaki S, Eshaghi-Rad J, Hodjati SM, Djomo A. 2014. Allometric equations for predicting aboveground biomass of beechhornbeam stands in the Hyrcanian forests of Iran. Journal of Forest Science. vol 60(6): 236-247. doi: https://doi.org/10.17221/39/2014-JFS.

Widyasari NAE, Saharjo BH, Solichin, Istomo. 2010. Pendugaan biomassa dan potensi karbon terikat di atas permukaan tanah pada hutan rawa gambut bekas terbakar di Sumatera Selatan. Jurnal Ilmu Pertanian Indonesia. vol 15(1): 41-49.

Yuniati D, Kurniawan H. 2013. Persamaan alometrik biomassa dan karbon untuk pendugaan simpanan karbon dalam mendukung upaya konservasi Savana Corypha utan. Jurnal Penelitian Sosial dan Ekonomi Kehutanan. vol 10(2): 75-84. doi: https://doi.org/10.20886/jpsek.2013.10.2.75-84.

Yusuf M, Sulistyawati E, Suhaya Y. 2014. Distribusi Biomassa di Atas dan Bawah Permukaan dari Surian (Toona sinensis Roem.). Jurnal Matematika dan Sains. vol 19(2): 69-75. 